
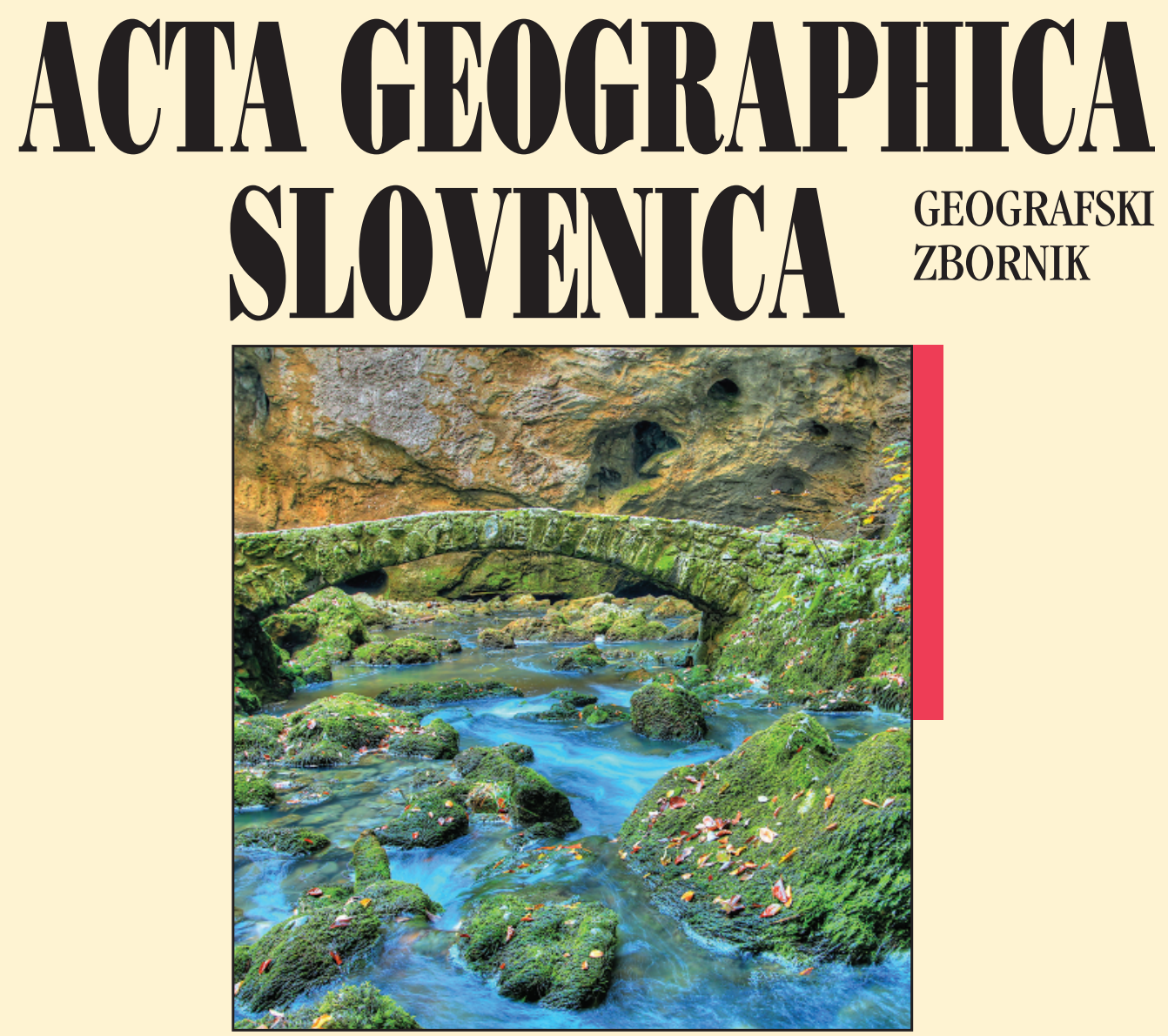


\section{ACTA GEOGRAPHICA SLOVENICA GEOGRAFSKI ZBORNIK \\ 59-1 • 2019}

\section{Contents}

Maja KOCJANČIČ, Tomislav POPIT, Timotej VERBOVŠEK

Gravitational sliding of the carbonate megablocks in the Vipava Valley, SW Slovenia

Małgorzata KIJOWSKA-STRUGAŁA, Anna BUCAŁA-HRABIA

Flood types in a mountain catchment: the Ochotnica River, Poland

Irena MOCANU, Bianca MITRICĂ, Mihaela PERSU

Socio-economic impact of photovoltaic park: The Giurgiu county rural area, Romania

Andrej GOSAR

The size of the area affected by earthquake induced rockfalls: Comparison of the 1998 Krn Mountains (NW Slovenia) earthquake $\left(M_{w} 5.6\right)$ with worldwide data

Matej GABROVEC, Peter KUMER

Land-use changes in Slovenia from the Franciscean Cadaster until today

Mojca FOŠKI

Using the parcel shape index to determine arable land division types

Mateja FERK, Matej LIPAR, Andrej ŠMUC, Russell N. DRYSDALE, Jian ZHAO

Chronology of heterogeneous deposits in the side entrance of Postojna Cave, Slovenia

\section{Special issue - Green creative environments}

Jani KOZINA, Saša POLJAK ISTENIČ, Blaž KOMAC

Green creative environments: Contribution to sustainable urban

and regional development

Saša POLJAK ISTENIČ

Participatory urbanism: creative interventions for sustainable development

Jani KOZINA, Nick CLIFTON

City-region or urban-rural framework: what matters more in understanding

the residential location of the creative class?

Matjaž URŠIČ, Kazushi TAMANO

The importance of green amenities for small creative actors in Tokyo:

Comparing natural and sociocultural spatial attraction characteristics

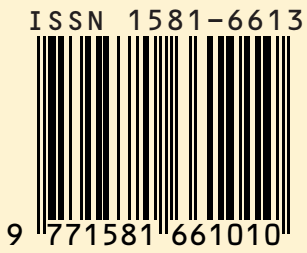




\section{ACTA GEOGRAPHICA SLOVENICA}

$59-1$

2019

ISSN: 1581-6613

COBISS: 124775936

UDC/UDK: 91

(C) 2019, ZRC SAZU, Geografski inštitut Antona Melika

International editorial board/mednarodni uredniški odbor: David Bole (Slovenia), Michael Bründl (Switzerland), Rok Ciglič (Slovenia), Matej Gabrovec (Slovenia), Matjaž Geršič (Slovenia), Peter Jordan (Austria), Drago Kladnik (Slovenia), Blaž Komac (Slovenia), Andrej Kranjc (Slovenia), Dénes Lóczy (Hungary), Simon McCharty (United Kingdom), Slobodan Marković (Serbia), Janez Nared (Slovenia), Drago Perko (Slovenia), Marjan Ravbar (Slovenia), Nika Razpotnik Visković (Slovenia), Aleš Smrekar (Slovenia), Annett Steinführer (Germany), Mimi Urbanc (Slovenia), Matija Zorn (Slovenia)

Editor-in-Chief/glavni urednik: Blaž Komac; blaz@zrc-sazu.si

Executive editor/odgovorni urednik: Drago Perko; drago@zrc-sazu.si

Chief editor for physical geography/glavni urednik za fizično geografijo: Matija Zorn; matija.zorn@zrc-sazu.si Chief editor for human geography/glavna urednica za humano geografijo: Mimi Urbanc; mimi@zrc-sazu.si

Chief editor for regional geography/glavni urednik za regionalno geografijo: Drago Kladnik; drago.kladnik@zrc-sazu.si

Chief editor for spatial planning/glavni urednik za regionalno planiranje: Janez Nared; janez.nared@zrc-sazu.si

Chief editor for rural geography/glavna urednica za geografijo podeželja: Nika Razpotnik Visković; nika.razpotnik@zrc-sazu.si Chief editor for urban geography/glavni urednik za urbano geografijo: David Bole; david.bole@zrc-sazu.si

Chief editor for geographic information systems/glavni urednik za geografske informacijske sisteme: Rok Ciglič; rok.ciglic@zrc-sazu.si

Chief editor for environmental protection/glavni urednik za varstvo okolja: Aleš Smrekar; ales.smrekar@zrc-sazu.si

Editorial assistant/uredniški pomočnik: Matjaž Geršič; matjaz.gersic@zrc-sazu.si

Issued by/izdajatelj: Geografski inštitut Antona Melika ZRC SAZU

Published by/založnik: Založba ZRC

Co-published by/sozaložnik: Slovenska akademija znanosti in umetnosti

Address/Naslov: Geografski inštitut Antona Melika ZRC SAZU, Gosposka ulica 13, SI - 1000 Ljubljana, Slovenija

The papers are available on-line/prispevki so dostopni na medmrežju: http://ags.zrc-sazu.si (ISSN: 1581-8314)

Ordering/naročanje: Založba ZRC, Novi trg 2, p. p. 306, SI - 1001 Ljubljana, Slovenija; zalozba@zrc-sazu.si

Annual subscription/letna naročnina: $20 €$ for individuals/za posameznike, $28 €$ for institutions/za ustanove.

Single issue/cena posamezne številke: $12,50 €$ for individuals/za posameznike, $16 €$ for institutions/za ustanove.

Cartography/kartografija: Geografski inštitut Antona Melika ZRC SAZU

Translations/prevodi: DEKS, d. o. o.

DTP/prelom: SYNCOMP, d. o. o.

Printed by/tiskarna: Tiskarna Present, d. o. o.

Print run/naklada: 350 copies/izvodov

The journal is subsidized by the Slovenian Research Agency and is issued in the framework of the Geography of Slovenia core research programme (P6-0101)/revija izhaja s podporo Javne agencije za raziskovalno dejavnost Republike Slovenije in nastaja v okviru raziskovalnega programa Geografija Slovenije (P6-0101).

The journal is indexed also in/revija je vključena tudi v: SCIE - Science Citation Index Expanded, Scopus, JCR - Journal Citation Report/Science Edition, ERIH PLUS, GEOBASE Journals, Current geographical publications, EBSCOhost, Geoscience e-Journals, Georef, FRANCIS, SJR (SCImago Journal \& Country Rank), OCLC WorldCat, Google scholar, and CrossRef

Oblikovanje/Design by: Matjaž Vipotnik.

Front cover photography: Stone bridge over the Rak River on the outskirts of the Rakov Škocjan polje, which is otherwise known for its beautiful natural bridges (photograph: Matej Lipar).

Fotografija na naslovnici: Kamniti most čez reko Rak na obrobju kraškega polja Rakov Škocjan, ki je sicer bolj znano po čudovitih naravnih mostovih (fotografija: Matej Lipar). 


\section{THE IMPORTANCE OF GREEN AMENITIES FOR SMALL CREATIVE ACTORS IN TOKYO: COMPARING NATURAL AND SOCIOCULTURAL SPATIAL ATTRACTION CHARACTERISTICS}

Matjaž Uršičc, Kazushi Tamano

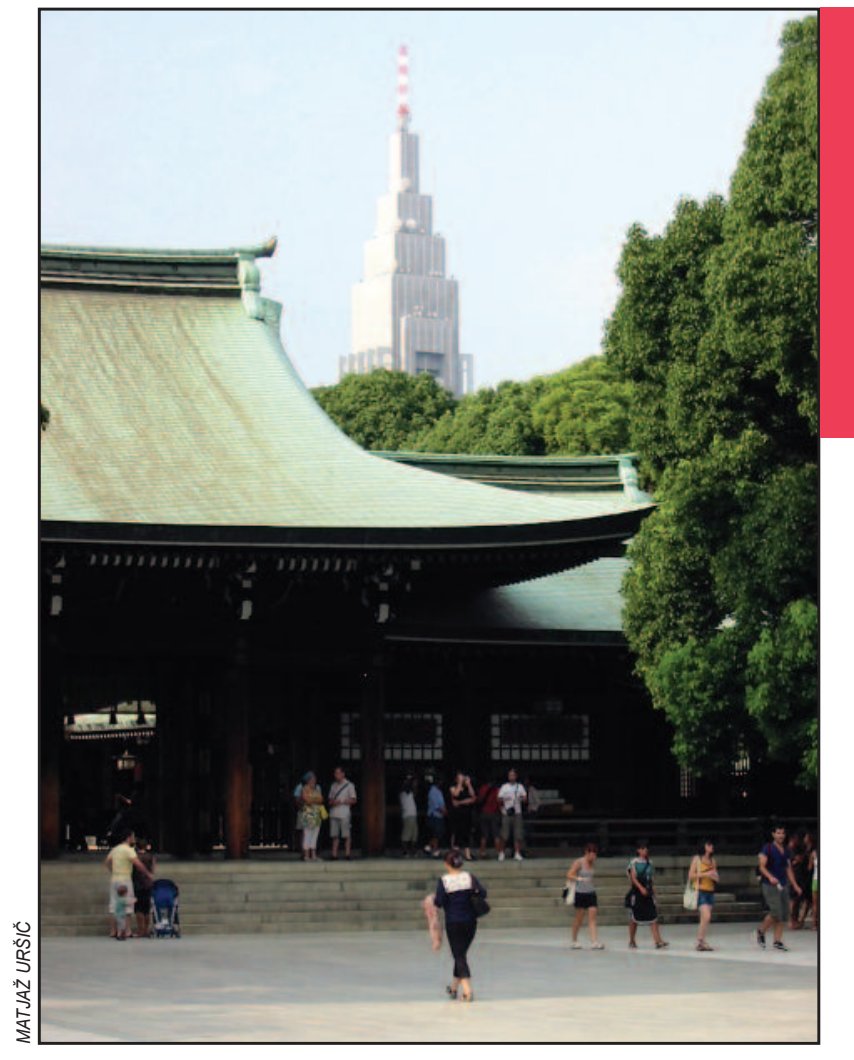

In intensely urbanized Tokyo, green areas are of great importance. 


\title{
The importance of green amenities for small creative actors in Tokyo: Comparing natural and sociocultural spatial attraction characteristics
}

\begin{abstract}
In the last decade, the Japanese authorities have invested considerable effort and economic resources into constructing developmental models that can help build a friendlier environment for the domestic creative economy. Due to Tokyo's specific natural and sociocultural characteristics, these efforts have had mixed effects on small creative groups. Based on an analysis of spatial attraction factors for individuals from various creative occupations, this article identifies how important green or natural amenities are in comparison with other sociocultural characteristics for small creative groups. The analysis of data acquired through semi-structured interviews indicates that green amenities do not play a primary role in the spatial distribution of small creative groups, but they do play a very important secondary role in cases when creative workers balance similar spatial attraction characteristics in specific areas in Tokyo.
\end{abstract}

KEY WORDS: spatial attraction factors, natural amenities, green amenities, creative sectors, creative ecosystem, small creative actors, Tokyo

\section{Pomen zelenih dobrin za male kreativne akterje v Tokiu - Primerjava naravnih in družbeno-kulturnih značilnosti prostorske privlačnosti}

POVZETEK: V zadnjem desetletju so japonske oblasti vložile veliko truda in ekonomskih virov v izdelavo razvojnih modelov, ki bi pomagali zgraditi prijaznejše okolje za domačo kreativno ekonomijo. Ta prizadevanja so zaradi specifičnih naravnih in družbeno-kulturnih značilnosti Tokija različno vplivala na majhne ustvarjalne skupine. Na podlagi analize faktorjev prostorske privlačnosti za posameznike iz različnih kreativnih poklicev smo v članku ugotovili, kako pomembne so zelene, tj. naravne dobrine v primerjavi z drugimi socialno-kulturnimi značilnostmi, ko gre za majhne ustvarjalne skupine. Analiza podatkov, pridobljenih prek polstrukturiranih intervjujev, razkriva, da zelene dobrine nimajo primarne vloge za prostorsko distribucijo majhnih kreativnih skupin, vendar imajo zelo pomembno sekundarno vlogo v primerih, ko kreativni delavci primerjajo podobne značilnosti prostorske privlačnosti na določenih območjih Tokija.

KLJUČNE BESEDE: faktorji prostorske privlačnosti, naravne dobrine, zelene dobrine, kreativni sektorji, kreativni ekosistem, mali kreativni akterji, Tokio

\section{Matjaž Uršič}

University of Ljubljana, Faculty of Social Sciences, Department of Sociology

matjaz.ursic2@guest.arnes.si

\section{Kazushi Tamano}

Tokyo Metropolitan University, Graduate School of Humanities, Department of Behavioral Social Sciences tamano@k.email.ne.jp

The article was submitted for publication on September $29^{\text {th }}, 2016$.

Uredništvo je prejelo prispevek 29. septembra 2016. 


\section{Introduction}

Global structural changes in trade and industrial production have affected the Japanese economy, which, due to its relative dependence on the domestic market (Kenkyujo 2007; Miyazaki 2008), is increasingly investing in innovative technologies and production, which are intended to open new markets and generate economic growth. In this view, creative industries, often referred to as the creative economies, are increasingly seen as a valuable tool for diversifying the local economic base and replacing jobs lost in traditional industrial and service sectors (Rausch and Negray 2006; Bole 2008; Chapain, Clifton and Comunian 2013; Gielen 2013; Kozina 2016). Creative industries are becoming a more important segment of urban economies, but the share of creative employees in Japan is increasing slowly in comparison to other economically developed countries (Sasaki 2003; Yoshimoto 2009).

Although Japan cannot be identified as a typical liberal market, but rather as a special form of »coordinated market economy « (Hall and Soskice 2001, 8), the transformation of global markets and production chains, the rise of digitalization, and informatization have radically changed the position of the employed in small creative firms that were traditionally embedded in manufacturing (Fujita and Hill 2005; Karatsu 2001). New types of production that intensified in the 1990s and demanded greater flexibiliation, internationalization, quicker production, and fast transferability of knowledge were less favorable for Japanese creative groups embedded in very specific historical, cultural, and political circumstances. In this regard, Clifton, Cooke, and Hansen $(2013,204)$ state that "varieties of capitalism « depending on specific national environments differently influence the location dynamics of the creative class. Similarly, Godina (2015) mentions the case of Japan, which shifted into the capitalist system while being strongly embedded and path-dependent on place-specific traditions, rituals, and cultural practices. Due to these specific contextual and spatial characteristics, the Japanese creative economy was better prepared for »incremental or coordinated innovation rather than the »radical « (i.e., disruptive) innovation model typical for liberal markets (Nemet 2009, 702). The circumstances described were favorable for powerful large companies supported by government institutions and banks, which attracted the majority of the creative workforce.

Today, the main economic power and creative employment still resides within large companies, but in the last decade a trend in an increase in small creative groups and individuals has been noticed; that is, small creative firms that try to establish themselves in a very competitive market (Sasaki 2003; Hanzawa 2009; Kon 2010; Goto 2014). Japanese policymakers often neglected the significance of smaller firms, which is of huge importance in the case of highly economically vulnerable, grassroots creative activities. From this perspective, establishing conditions to better empower small creative groups to create (self-)employment and thrive in the context dominated by large firms is of extreme importance.

This article analyzes specific social-physical elements of the economic environment in which creative groups are embedded. Namely, we explore what kind of working environment and conditions are expected from the perspective of these groups. For this purpose, we pay particular attention to how these groups perceive the importance of »soft and hard location factors " (Musterd and Murie 2010; Martin-Brelot et al. 2010; Alfken, Broekel and Sternberg 2015) in their working and living environment. Whereas hard location factors mainly apply to the availability of certain resources, soft location factors apply to improvements in one's general quality of life or lifestyle. In this relation, we compare whether natural or green spatial attraction factors such as parks, open recreational areas, and other environmental factors are of higher importance for the new bottom-up emerging creative firms in comparison to other sociocultural attraction characteristics of Tokyo. On the basis of interviews, a questionnaire, and official statistics, we analyze whether existing places and urban conditions provide optimal circumstances for the long-term formation of small (bottom-up) creative actors.

\section{Conceptualization: spatial attraction characteristics and the Tokyo creative ecosystem}

As the importance of the innovation sector and creative economies rises, Tokyo and other Japanese cities are increasingly trying to improve their spatial advantages and create an environment of micro-locations that are better adapted for creative businesses (Tokyo Metropolitan Government 2014; Kim 2015). The advantages of individual locations for creative industries are reflected through various factors, ranging from 
green areas to the amount of rent for business premises, transport links, access to customers, lifestyle orientations of employees, extent of social networks, and proximity to sociocultural activities and leisure. All of these factors are an integral part of the creative ecosystem, defined as an environment that supports or is "focused on creative-based activities « (Rivas 2011,4). It comprises places following the example of the creative city and economy in the form of creative industries, following specialized ways of exchanging, interacting, and communicating; people, (i.e., members of the creative class); and social and cultural capital, social networks, and so on (Scott 2006; Markusen 2006; Rivas 2011; Bell and Jayne 2004; Florida 2010).

It can be presumed that, when searching for appropriate working conditions, small innovative firms apply the system of progressive elimination or tapering of the most negative elements and pursuit of the most suitable options that meet their development needs. In doing so, they rely on what behavioral economics calls cost-benefit analysis, or CBA (Tevfik 1996), and decide on a suitable location only when they feel satisfied with the majority of conditions that minimize unnecessary costs (Giddens 1984). In accordance with their perception of contextual and spatial elements, potential users of a site for creative activities rigorously assess all possible costs and do not only pay attention to the economic price of rent or purchase cost of the premises. For example, the quality of natural amenities, transport accessibility, cost of access to the market (customers), mental/emotional effort required to operate at the location, level of cultural heterogeneity, access to various amenities, services, cooperation between similar companies, openness of the local community, and so on are all elements evaluated by potential users. For potential users, each of these elements can represent a significant cost, inappropriate effort, or, on the other hand, comfort and relief, which may significantly affect their work and either discourage or attract them to a location. These are the so-called push/pull factors in attracting creative groups (Gottlieb 1994; Musterd and Gritsai 2012; Krätke 2011).

Any suitable location for developing a creative milieu comprises a number of pull factors that successfully attract specific groups of people. In doing so, it is important to emphasize that specific pull factors heavily depend on the decisions of city or national authorities about how to intervene in space. Such is also the case of green areas, which are scarce in Tokyo's physical space. Although the central districts of Tokyo generally have some green areas such as the Imperial Palace and large private gardens, many of these spaces are not accessible to the public. Kobayashi $(2015,8)$ writes that in Tokyo »spaces where forests and the natural environment can be experienced are actually very limited. «A comparison of Tokyo with other global cities shows that Tokyo has an extremely low percentage of publicly accessible parks, gardens, squares, and cemeteries (Figure 1).

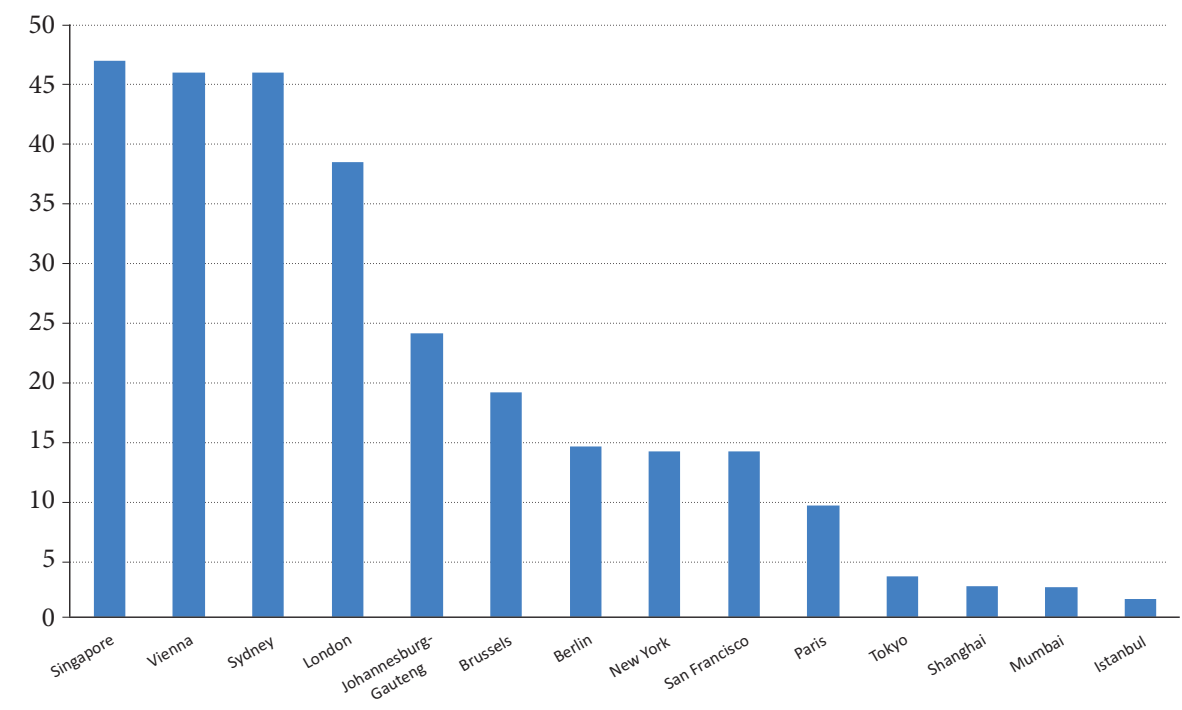

Figure 1: World cities'public green spaces (parks and gardens), percentage by proportion of area (Source: WCCF, World Cities Culture Report 2012, 2015). 
From this perspective, it seems that the »Tokyo model « of a sustainable development strategy is not particularly concerned with the strategic integration of green spaces, but relies on the implementation of incremental (i.e., very particular) projects connected to the development of green areas. Past urban development in Tokyo considerably undermined many natural features and amenities that make other global cities attractive in the first place. The rapid growth of the urban population and increasing density have put pressure on the use of space for construction where natural amenities were barely integrated into public space.

Although at first glance the importance of nature for developing the local milieu and small creative groups for city development seems small, this does not mean that global cities cannot be affected by the availability of green spaces in the long term. For example, Florida (2005) asserts that specific factors that deeply affect the spatial distribution of creative sectors are at first glance more visible than other factors that may greatly influence the attraction potential of specific cities in the future. Such changes may occur at the micro or local level and are sometimes less noticeable but still have a deep and important impact. One such factor is described as »urban sprawl and ecological decay» (Florida 2005, 172) and could gradually significantly change the attraction hierarchy of global cities in the long term.

\section{Methodology and research process}

The major goal of the research was to accumulate various layers of data to make it possible to analyze the influence of place and environment on the organization of work for specific parts of Japanese creative sectors. In this regard, we approach small creative groups and individuals from the perspective of "creative occupations «; that is, by focusing "more closely on what cultural workers do rather than what they make" (Markusen et al. 2008, 25) and thus not taking into account the entire range of those employed in a particular sector of the creative industries. Relying on Florida's (2005) broad definition of the creative class, based on which we identified the creative fields of people included in the study, like DeNatale and Wassall (2006) we sought to narrow down the large occupational categories by identifying specific components of the creative cluster (e.g., defining enterprises and individuals that directly and indirectly produce cultural products in a specific area), the creative workforce (e.g., defining the thinkers and doers trained in specific cultural and artistic skills that drive the success of creative industries in specific areas), and the creative community (e.g., defining a geographic area with a concentration of creative workers, creative businesses, and cultural organizations in specific locations of Tokyo). The combination of specific components of the creative cluster, creative workforce, and creative community allowed us to filter out persons not directly engaged in creative tasks and at the same time to capture the creative employed and self-employed that are usually not considered part of the creative industries or creative workforce (e.g., general software, art crafts, etc.).

There were two stages in the research. The basic research model first included acquiring qualitative data through face-to-face interviews and then quantitative data through questionnaires. As such, in the first stage, key personnel (e.g., directors, managing directors, key developers, engineers, researchers, etc.) in institutions that provide jobs and attract a large number of self-employed creative individuals were interviewed. A total of twenty-three interviews in twenty different institutions were carried out from August to September 2014. Such institutions included co-working spaces, start-up incubators, and art and creative labs in Tokyo's central wards of Minato, Chuo, Shibuya, Shinjuku, Chiyoda, Sumida, Bunkyo, Taito, and Shinagawa (marked dark grey in Figure 2). After detailed interviews with key personnel in these institutions, the second stage of the research process addressed creative individuals from small firms (mainly ranging from one to five employees) that are associated with and directly use the services or working spaces in these institutions. As such, the key personnel in the institutions provided a sort of entry point for the second stage of the research process, which surveyed the creative individuals through a semi-structured questionnaire. Altogether, 102 respondents from thirty-five different institutions that spend their working time in Tokyo's central wards were surveyed from September to November 2014.

The data acquisition method used is a form of two-stage snowball sampling or chain (referral) sampling (Atkinson and Flint 2004; Morgan 2008; Voicu 2011). Such a non-probability sampling technique in which those interviewed (in our case, the key personnel in creative support institutions) in the first stage allow the researcher to access additional subjects (from among people that are part of institution's social network) for a questionnaire in the second stage of the research process is often used for populations that are difficult for researchers to access. In particular, independent creative workers that are highly mobile, 


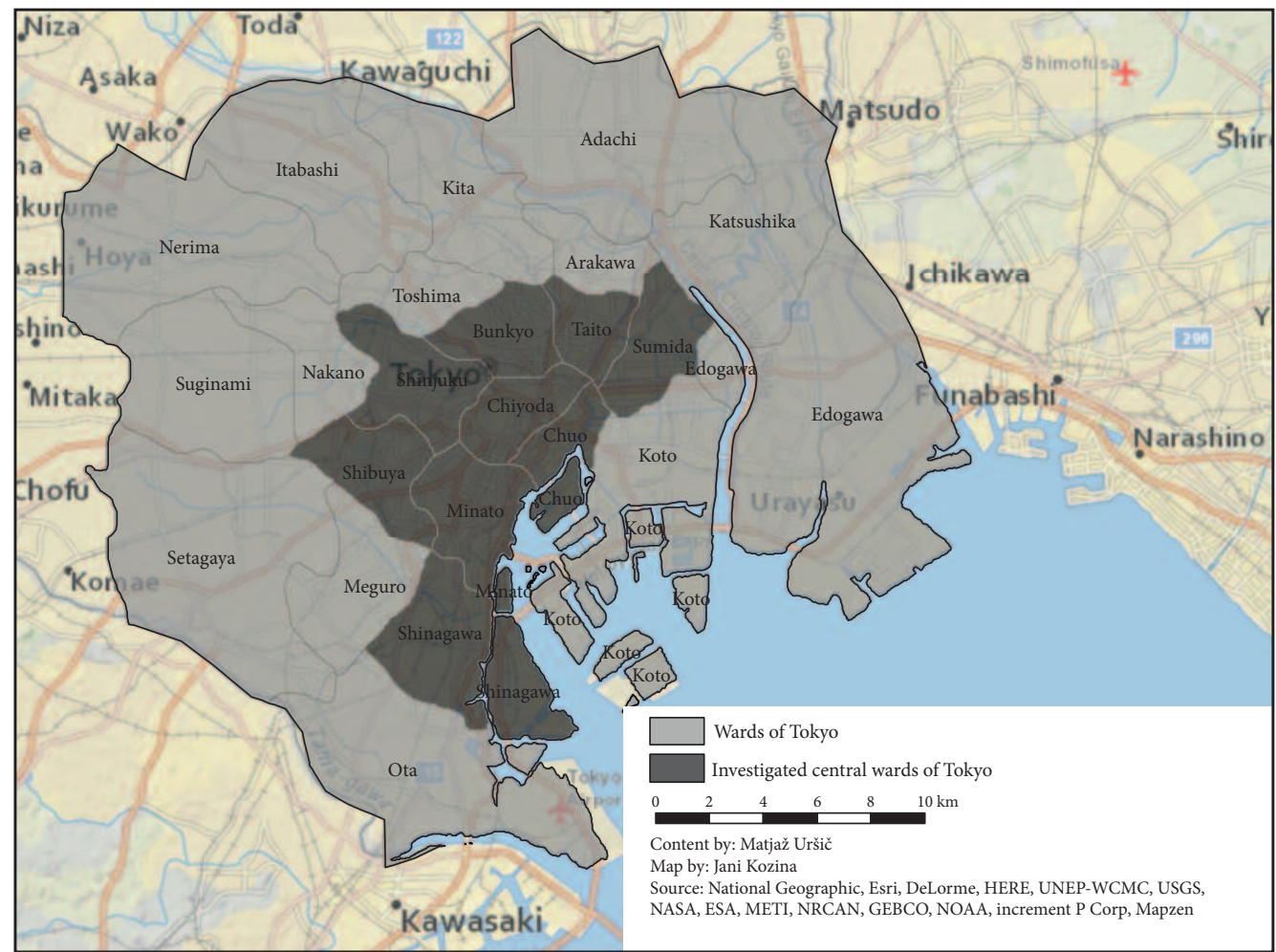

Figure 2: Tokyo's central wards included in the analysis.

non-sedentary, possess special skills or innovative approaches, and highly value privacy perfectly fit the description of a population that is difficult to access for researchers. In our sample, $70.6 \%$ of respondents from the questionnaire belonged to the $26-35$ and $36-45$ age groups, $58 \%$ were male, and in terms of social status they were middle class ( $40 \%$ earned $¥ 150,001$ to $¥ 300,000$ per month). Due to the snowball sampling technique, it was impossible to focus only on a specific creative occupation or concentrate on analyzing a very specific creative industry; instead, we used the »occupation by-industry approach " (Markusen et al. $2008,37)$ to analyze specific occupations within larger creative industry fields. The research focuses on a general analysis of spatial factors in the creative ecosystem for small creative groups and individuals in Tokyo's central districts. The questionnaire was divided into various sections that included general questions regarding Tokyo's creative economy and details ranging from individuals' creative field, spatial factors, and value orientations to their relation toward urban development and demography. The individuals included in the questionnaire were based in very different creative occupations ( $27 \%$ arts and culture creation, $24 \%$ architecture, $15 \%$ general software and computer games, $12 \%$ crafts, $11 \%$ design, and $11 \%$ other groups). The open-question (qualitative) data were analyzed separately, and the quantifiable data were appropriately coded and inputted into the SPSS database for further analysis.

\section{Analysis of results: the role of natural and sociocultural spatial attraction characteristics for small creative groups in Tokyo}

The collected data confirm the importance of specific spatial factors for creative individuals that work in Tokyo's central districts. Undoubtedly, the most important spatial factor in the case of Tokyo is access to mobility infrastructures. In comparison to European cities, where personal networks are an important part 
of spatial attraction characteristics (Musterd and Gritsai 2012), their role does not seem so substantial in the case of Tokyo. Instead, the importance of mobility infrastructures was stressed on various occasions both in interviews and in quantitative data collected from the questionnaire. When asked: »How important are the following factors when you are choosing the location of work? « creative individual respondents put the location and its accessibility by public transport at the top of the list (see Figure 3).

More than $85 \%$ of respondents replied that the vicinity of public transport routes and networks is a very important characteristic when choosing the present location of work. Similarly important is the need to have adequate work infrastructure (84\%) and a good (attractive) interior design of the workplace (81\%). The location of work must also have qualities that allow personal growth and individual development (79\%). How important the location is in terms of mobility is further stressed by the need to be accessible to customers (79\%) and indirectly through some other factors on the list (e.g., the vicinity of Tokyo's main districts, the proximity of useful services and offices, etc.). The importance of greenery, sports, and recreation facilities ranks at the very bottom of important factors because they are not perceived by creative groups as absolutely necessary for work. The importance of transport accessibility is very understandable due to Tokyo's extreme metropolitan size, its density, and the distances one needs to travel. Transport accessibility is key for other services, customers, wellbeing, and sustaining formal and informal networks, which from the perspective of creative individuals offer enormous multiplicative effects and add to the quality of one's work.

Transport accessibility also stands out as one of the main factors in cases when respondents wanted to change the present location of work. Approximately, one-third $(32.4 \%)$ of respondents wanted to relocate in the next three years for various reasons (e.g., to find another job in the same or different innovative field, to open a new company, etc.). When asked: »In comparison to your present job location, what are the main advantages of the location that you listed as your favorite working environment in Tokyo? « the advantage most often named (in $70.7 \%$ of cases) was location and its proximity to main public transport routes (Figure 3). Even though respondents may work in a well-networked location in terms of transport, they have aspirations to improve it in order to obtain a better workplace.

In comparison to other spatial factors that stand out when choosing the present location for work (Figure 3) for example, the need for adequate work infrastructure, good interior (attractive) design of the workplace, or affordable rent at the workplace when choosing a desired location for work the respondents again stressed the importance of transport accessibility as the main variable for improving their working conditions and businesses. It seems that their perception of a desired location is based on the experience that they acquired during past years of work in the creative field. In economically very competitive environments such as Tokyo, the best locations are occupied by the strongest creative economic actors (i.e., large firms), whereas small creative firms are left to pick secondary locations. Despite being located in central areas of Tokyo, small creative groups cannot afford the premium workplaces, but due to financial limitations choose secondary, peripheral locations inside central areas. Although these are still central locations, they have specific shortfalls, which can be recognized through respondents' indications that show the importance of other location factors (e.g., lots of green areas, good access to customers, the character of a neighborhood, and proximity to similar companies and professional colleagues). Although small creative groups put additional emphasis on other location factors, they first want to improve their accessibility and then obtain access to better »secondary « factors. In this sense, they are aware that location on the periphery of the central districts prevents them from developing their full potential because of the missing additional factors that are not at the selected location.

In the case of Tokyo, the accessibility of transport infrastructure represents the top of the »hard location factors « (Musterd and Gritsai 2012, 346), which also include other variables such as rent, work infrastructure, salary, and so on. The research findings indicate that hard location factors play a significant role in attracting young creative workers. Although the results suggest that hard factors are of extreme importance when choosing the location of work, it is important to mention that "soft factors " (Murphy and Redmont 2008, 36) also play an important role. Soft location factors usually include contextual elements that add to enhancement of social aspects in specific environments. In the case of Tokyo, green, recreational areas and natural amenities were perceived by small creative groups as socially pleasant leisure places that add to the personal quality of life. In our study, they are identified as part of soft attractive factors due to their functional role as a catalyzer of social engagement or sociability. In this sense, soft factors 


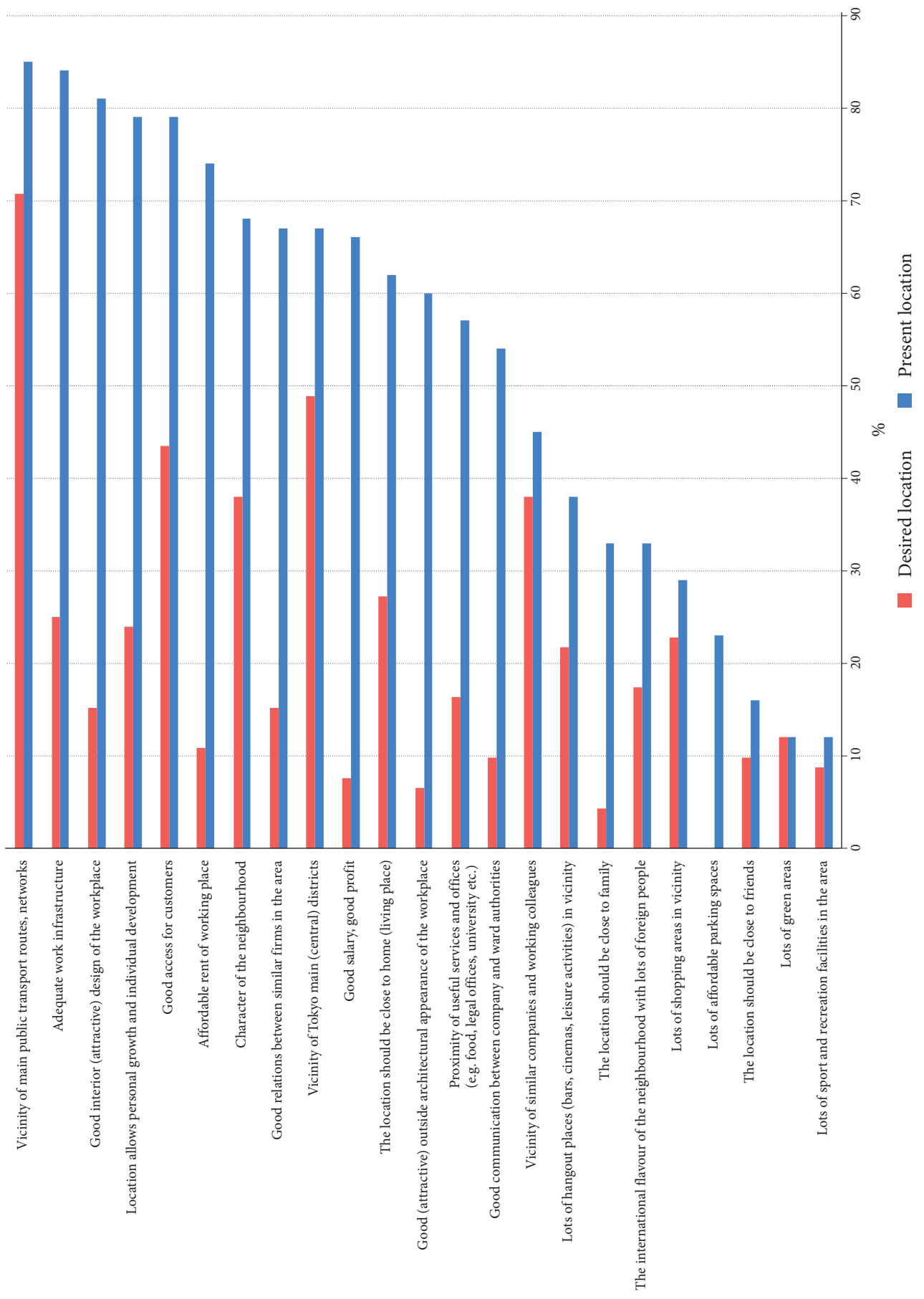


prove to be decisive in cases when creative individuals compare working spaces with similar transport accessibility, price of rent, or work infrastructure. Similar findings are drawn also from the ACRE study (2010) and other authors (Musterd and Murie 2010; Martin-Brelot et al. 2010; Ravbar 2011) that analyze soft factors in Europe.

Based on these studies, we may speculate that, when comparing working spaces with similar transport accessibility, price of rent, or work infrastructure, creative individuals would prefer to choose locations that offer better soft location attributes (e.g., plenty of greenery, lots of sports and recreation facilities, good access to customers, a good neighborhood character, etc.), even at the expense of some of the hard attraction factors such as a good salary or a large number of affordable parking spaces. Even more, the data from Figure 3 suggest that, based on their experience, creative individuals look to soft location factors when making a final decision on where to possibly relocate. It appears that in the "second stage of creative working development (i.e., after some years of experience at a specific location), individuals recognize the importance of or can afford more soft location attributes when they search for a new desirable location. According to the data in Figure 3, it can be observed that some soft location factors (e.g., green areas, sports and recreation facilities, the character of the neighborhood, proximity to similar companies and professional colleagues, etc.) climbed the preference ladder in comparison to their position between the attraction characteristics at the present location of work. In general, transport accessibility as the most important spatial factor stayed at the top position, but the importance of other hard location factors such as work infrastructure or rent considerably diminished in the second step.

The interplay between hard and soft location factors can also be observed through the analysis of other factors, which emerged after detailed questioning of the interviewees. For example, the creative individuals were asked to form specific opinions regarding the statements presented in Figures 4 and 5.

The analysis shows that the image of physical location as the dominant spatial factor in the creative ecosystem is softened by the sensitivity of the respondents toward specific socio-spatial transformations that are occurring in Tokyo and may change the character of their working environment in the long term. They are aware that economic development results in new jobs and supports their work aspirations (Statement 2 in Figure 4) but are also fully aware that intense urban restructuring, renovation, and urban competitiveness may diminish the quality of their living and working environment in the long run (Statements 1, 3, 4, and 5 in Figure 4). Although Statements 1 and 4 seem ambiguous at first glance, it is understandable

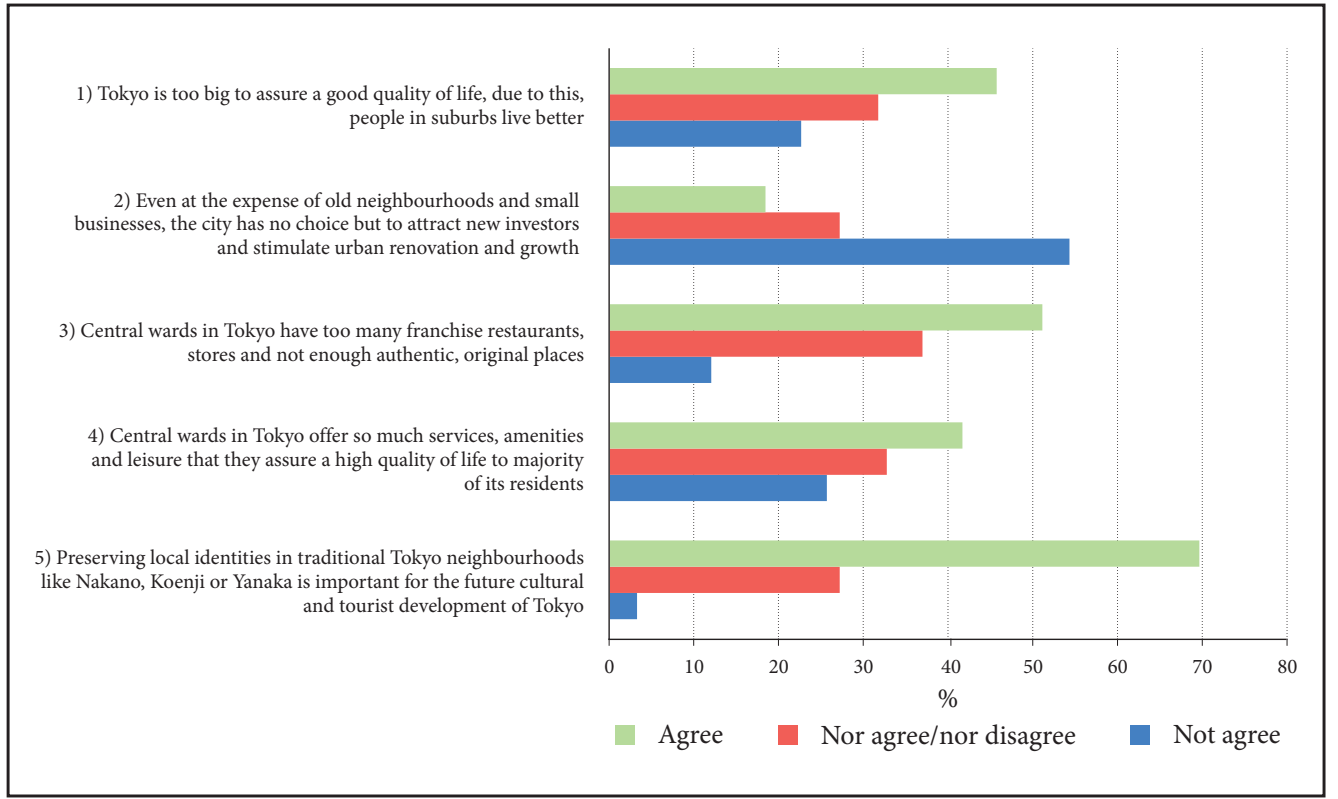

Figure 4: Please state how much you agree or disagree with the following statements. 


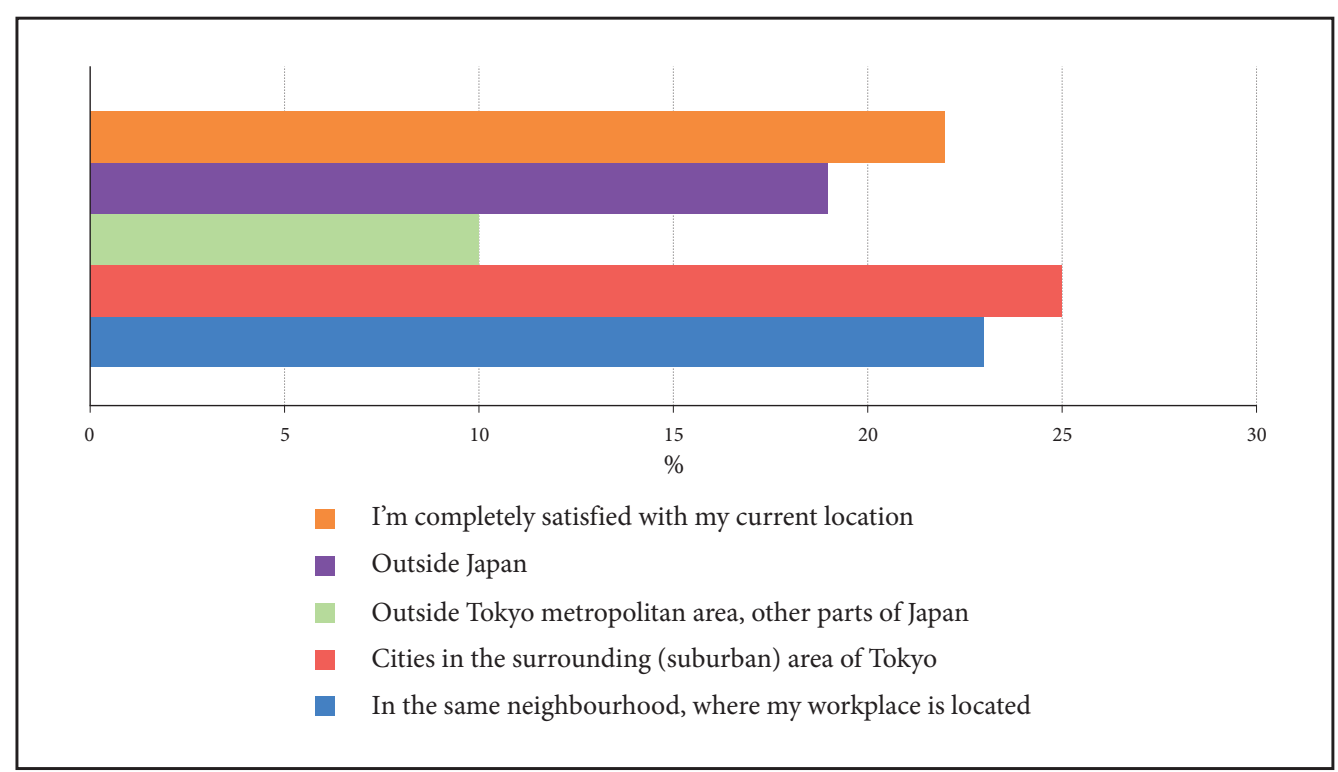

Figure 5: Where would you like to live if you could freely choose your location?

that respondents highly value the advantages offered by both central areas (e.g., access to services and infrastructure) and suburban areas (e.g., access to green areas and natural amenities, less traffic, and urban density; see Figure 5).

Similarly to the data in Figures 4, 5, and 6, the respondents latently show a high interest in soft location factors, which gain more importance when not directly linked to working conditions. In Figure 6 , the respondents were asked to evaluate the main attraction factors for home; that is, the location where they (would like to) live.

In the Japanese context, which highly values work and the work ethic, the hard location factors that add to work still remain at the top of the priority list for creative workers. However, when offered additional possibilities of evaluation, the quality of the living and working environment is not perceived by creative individuals only in terms of access to hard spatial factors and economic incentives, but also in terms of access to natural amenities (e.g., proximity to large natural areas and city parks), which scored particularly high in the evaluation of soft factors that are important when choosing a place to live.

\section{Conclusions}

The research showed that Japanese creative workers in small firms highly value specific spatial factors that add to their personal growth and quality of work. It also showed that the Tokyo creative ecosystem is still based on hard location factors such as access to public transport and provision of adequate working infrastructure, whereas soft location factors such as natural amenities, sports and recreation facilities, diversity, and international flavor play an important secondary role. Natural amenities thus do not play a primary role for the distribution of small creative firms, but they do play a very important secondary role in cases when creative workers balance similar hard attraction characteristics for specific areas in Tokyo. In the case of Tokyo's small creative groups, green amenities, in order to "survive « in the very harsh inter-company competitive environment, do not function as an important category for selecting a working space. In order to improve their status, creative workers in small firms would rather obtain access to a better working location than to greenery, parks, or natural and recreational areas. 


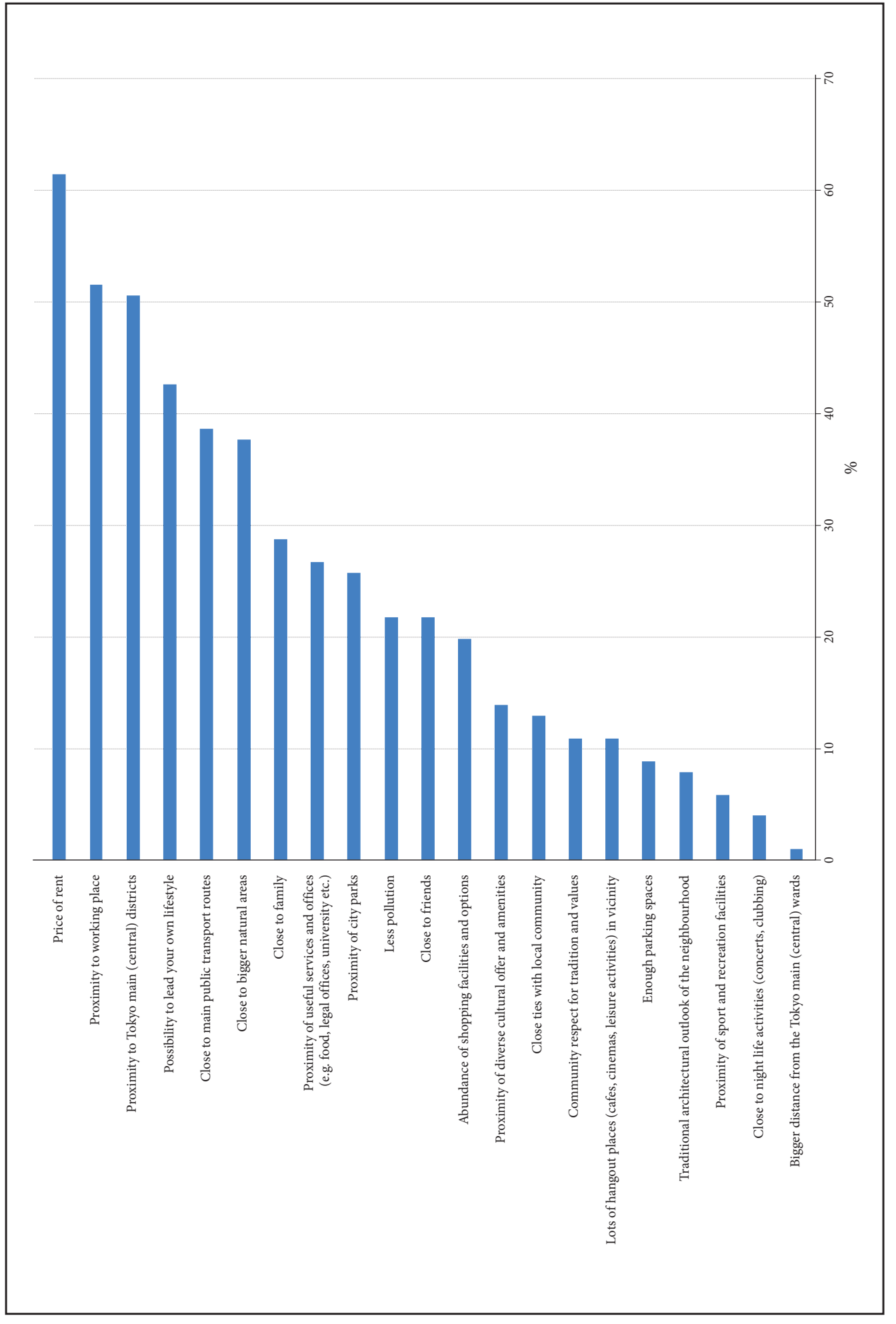


The strong hierarchy of attraction characteristics for work shows that policy could take some precautionary measures to ease the burden of small and vulnerable creative actors that are just entering a very competitive market. It also points to the relatively diminished importance of natural spatial attraction characteristics, which is not the case in other cities and countries in the world (see Poljak Istenič 2016, WCCF 2012 2015; Ravbar, Bole and Nared 2005; Huggins and Clifton 2011; Clifton and Kozina 2015). If internationalization in terms of transfer of sociocultural trends really influences the creative global sectors in Tokyo, the importance of natural amenities could significantly change in the future. Some authors (Møller 2008; Moreno-Peñaranda 2011) have already noticed the increasing importance of natural and green areas as an asset for socio-spatial development. From this perspective, natural amenities that are currently not on the priority list of small creative groups in Tokyo's central districts could greatly influence the distribution and density of creative occupations in the future. Specific urban policies in Tokyo on a grand scale (i.e., at the instrumentalist level) already focus on the development of green areas in central parts of the city (e.g., the Marunouchi project, Toranomon, the Umi no Mori »Sea Forest« marine park, etc.), but they do not systematically integrate environmental factors into the scheme of sustainable development and connect it with general urban development of the city.

A similar situation is reflected at the more general level of urban competitiveness of cities, where Tokyo is seeking to retain its role among global cities and to implement various strategies and projects to revitalize its economic potential (see Tokyo Metropolitan Government Bureau ... 2013; Tokyo Metropolitan Government 2014). These strategies mainly rely on improving hard location factors, which partly helps in revitalizing specific city areas but also opens the discussion on whether the strategies should have been more oriented toward soft location factors, including improving quality and access to natural, green, and recreational areas, which also play an important role in other global cities (Sassen 2001; Machimura 1997; Pain et al. 2015).

ACKNOWLEDGEMENT: The authors would like to thank the Japan Society for the Promotion of Science (JSPS) and the Japan Foundation (JF) for research support.

\section{References}

ACRE 2010. Accommodating creative knowledge - competitiveness of European metropolitan regions within the enlarged Union - Published reports. Internet: http://www.acre.socsci.uva.nl/results/reports.html (15. 5. 2015).

Alfken, C., Broekel, T., Sternberg, R. 2015: Factors explaining the spatial agglomeration of the creative class: empirical evidence for German artists. European Planning Studies 23-12. DOI: https://doi.org/10.1080/ 09654313.2014.979767

Atkinson, R., Flint, J. 2004: Snowball Sampling. Encyclopedia of social science research methods. Thousand Oaks.

Bell, D., Jayne, M. 2004: City of quarters: urban villages in the contemporary city. London.

Bole, D. 2008: Cultural industry as a result of new city tertiarization. Acta geographica Slovenica 48-2. DOI: https://doi.org/10.3986/AGS48202

Chapain, C., Clifton, N., Comunian, R. 2013: Understanding creative regions: bridging the gap between global discourses and regional and national contexts. Regional Studies 47-2. DOI: https://doi.org/10.1080/ 00343404.2013 .746441

Clifton, N., Cooke, P., Hansen, H. K. 2013: Towards a reconciliation of the "context-less « with the »spaceless «? The creative class across varieties of capitalism: New evidence from Sweden and the UK. Regional Studies 47-2. DOI: https://doi.org/10.1080/00343404.2012.665991

Clifton, N., Kozina, J. 2015: Identifying the locational factors of the creative class: temporal and spatial implications. Lecture at the University of Oxford, 20. 8. 2015. Oxford.

DeNatale, D., Wassall, G. H. 2006: Creative economy research in New England: A reexamination. Boston.

Florida, R. 2005: Cities and the creative class. New York.

Florida, R. 2010: The Great reset: how new ways of living and working drive post-crash prosperity. New York. 
Fujita, K., Hill, R. C. 2005: Innovative Tokyo. World Bank Policy Research Working Paper 3507. Internet: https://www.msu.edu/user/hillrr/InnovativeTokyo\%20Text.pdf (16.8. 2015).

Giddens, A. 1984: The constitution of society - outline of the theory of structuration. Cambridge.

Gielen, P. 2013: Creativity and other fundamentalisms. Santa Monica.

Godina, V. 2015: Zablode postsocializma. Ljubljana.

Gottlieb, P. 1994: Amenities as an economic development tool: is there enough evidence? Economic development quarterly 8-3. DOI: https://doi.org/10.1177/089124249400800304

Goto, K. 2014: Creative Sangyo no Sangyososhiki to Seisakukadai. Nihon Seisaku Kinyu Koko Ronshu 22-2.

Hall, P., Soskice, D. 2001: Varieties of capitalism: the institutional foundations of comparative advantage. Oxford

Hanzawa, S. 2009: Nippon no Sozosangyoshuseki. Creative city and social inclusion. Tokyo.

Huggins, R., Clifton, N. 2011: Competitiveness, creativity, and place-based development. Environment and Planning A 43-6. DOI: https://doi.org/10.1068/a43559

Karatsu, H. 2001: Small and medium-sized enterprise in Japan. Journal of Japanese Trade and Industry. Internet: http://www.jef.or/jp/en/jti/200111_009.html (5.6.2010).

Kenkyujo, N. S. 2015: Nen Project Team 2007. Tokyo.

Kim, C. 2015: Locating creative city policy in East Asia: neoliberalism, developmental state and assemblage of East Asian cities. International Journal of Cultural Policy 23-3. DOI: https://doi.org/10.1080/ 10286632.2015.1048242

Kobayashi, Y. 2015: The need for »Rebuilding Tokyo« with the 2020 Tokyo Olympics as Impetus. Tokyo.

Kon, K. 2010: Chiiki niokeru Chushokigyo no Hattensenryaku - Osaka Shiritsu Daigaku Daigakuin Sozotoshi Kenkyujo/Development Strategy of small and medium sized companies in regional areas - Creative Spaces and Urban Regeneration. Kyoto.

Kozina, J. 2016: Demographic characteristics of creative workers: under-activated development potentials in Slovenia? Acta geographica Slovenica 57-1. DOI: https://doi.org/10.3986/AGS.4602

Krätke, S. 2011: The Creative capital of cities: interactive knowledge creation and the urbanization economies of innovation. Chichester.

Machimura, T. 1997: Building a capital for emperor and enterprise: the changing urban meaning of Central Tokyo. Culture and the City in East Asia. Oxford.

Markusen, A. 2006: Urban development and the politics of a creative class: evidence from the study of artists. Environment and Planning A 38-10. DOI: https://doi.org/10.1068/a38179

Markusen, A., Wassall, G. H., DeNatale, D., Cohen, R. 2008: Defining the creative economy: industry and occupational approaches. Economic Development Quaterly 22-1. DOI: https://doi.org/10.1177/ 0891242407311862

Martin-Brelot, H., Grossetti, M., Eckert, D., Gritsai, O., Kovács, Z. 2010: The spatial mobility of the »Creative Class «: A European perspective. International Journal of Urban and Regional Research 34-4. DOI: https://doi.org/10.1111/j.1468-2427.2010.00960.x

Miyazaki, T. 2008: Garapagosuka suru Nippon no Seizogyo. Tokyo.

Morgan, D. L. 2008: The SAGE encyclopedia of qualitative research methods. New York.

Moreno-Peñaranda, R. 2011: Japan's urban agriculture: Cultivating sustainability and well-being. Our world, United Nations University. Internet: https://ourworld.unu.edu/en/japans-urban-agriculture-cultivating-sustainability-and-wellbeing (7.9.2016).

Murphy, E., Redmont, D. 2008: Location factors of creative knowledge companies in the Dublin Region The managers' view. Amsterdam.

Musterd, S., Murie, A. 2010: Making competitive cities. Oxford.

Musterd, S., Gritsai, O. 2012: The creative knowledge city in Europe: Structural conditions and urban policy strategies for competitive cities. European Urban and Regional Studies 20-3. DOI: https://doi.org/10.1177/ 0969776412439199

Møller, J. 2008: Villages in Landscapes - the importance of appearance. Annual conference, Nordic-Scottish University for Rural and Regional Development. Copenhagen.

Nemet, G. F. 2009: Demand pull, technology push, and government-led incentives for non-incremental technical change. Research Policy 38-5.

Pain, K., Van Hamme, G., Vinciguerra, S., Quentin, D. 2015: Global networks, cities and economic performance: Observations from an analysis of cities in Europe and the USA. Urban Studies 1-25. DOI: https://doi.org/10.1177/0042098015577303 
Poljak Istenič, S. 2016: Reviving Public Spaces through Cycling and Gardening. Ljubljana - European Green Capital 2016. Etnološka tribina 39-46. DOI: 10.15378/1848-9540.2016.39.06

Rausch, S., Negray, C. 2006: Does the creative engine run? A consideration of the effect of creative class on economic strength and growth. Journal of Urban Affairs 28-5. DOI: https://doi.org/10.1111/j.14679906.2006.00310.x

Ravbar, M., Bole, D., Nared, J. 2005: A creative milieu and the role of geography in studying the competitiveness of cities: the case of Ljubljana. Acta geographica Slovenica 45-2. DOI: https://doi.org/10.3986/ AGS45201

Ravbar, M. 2011: Creative social groups in Slovenia: Contribution to geographic studying of human resources. Acta Geographica Slovenica 51-2. DOI: https://doi.org/10.3986/AGS51204

Rivas, M. 2011: From creative industries to the creative place refreshing the local development agenda in small and medium-sized towns. Internet: http://www2.cetiqt.senai.br/ead/redige/index.php/redige/ article/view/112/170 (10.9.2015).

Sasaki, M. 2003: Sozosangyo ni yoru Toshikeizai no Saisei. Kikan Keizai Kenkyu 26-2.

Sassen, S. 2001: The Global city, New York, London, Tokyo. Princeton.

Scott, A. J. 2006: Creative cities: Conceptual issues and policy questions. Journal of Urban Affairs 28-1. DOI: https://doi.org/10.1111/j.0735-2166.2006.00256.x

Tevfik, N. 1996: Cost-benefit analysis, theory and application. Thousand Oaks.

Tokyo Metropolitan Government 2014: Tokyo-to Choki Vision. Tokyo.

Tokyo Metropolitan Government Bureau of Urban Development 2013. Tokyo no Kokusaikyosoryoku no isso no kyoka ni muketa Toshisaisei no Suishin. Tokyo.

Voicu, M. C. 2011: Using the snowball method in marketing research on hidden populations. Challenges of the Knowledge Society 1.

Yoshimoto, M. 2009: Creative Sangyo no Choryu 2. Nissei Kisoken REPORT (August 2009).

WCCF World Cities Culture Forum 2012, 2015: World cities culture report. London. 